УДК 616.33/.34-002.44-055.1-06]-036.87-037

DOI: $10.24061 / 1727-0847.18 .2 .2019 .6$

\title{
I.I. Дутка
}

Кафедра хірургії № 1 (зав. - проф. І.Ю. Полянський) Вищого державного навчального закладу

Украӥни «Буковинський держсавний медичний університет», Чернівиі

\section{КОМПЛЕКСНЕ ОЦІНЮВАННЯ МАРКЕРІВ РЕЦИДИВНИХ ВИРАЗКОВИХ КРОВОТЕЧ}

Резюме. Частота розвитку рецидивних виразкових кровотеч залишається на сталому рівні. Шкали Forrest, Glasgow Blatchford, Rockall $\epsilon$ недостатньо надійними. Мета роботи. Напрацювання комплексного підходу до прогнозування рецидивів виразкових кровотеч для створення інформативної шкали. Матеріал і методи. 203 хворих на виразкову хворобу, у 167 з яких виникла гостра виразкова кровотеча. У 24 хворих виник рецидив кровотечі. Оцінювали клінічні показники, клас кровотечі за Forrest, клас коморбідності, активність процесів окиснення ліпідів, білків і антиоксидантних чинників, фібринолітичної, протеолітичної активності плазми венозної крові, коагулограму. Провели генотипування РАІ1 (SERPINE 1). Встановлено, що передумовами виникнення рецидивних виразкових кровотеч $є$ дисбаланс у системі гемостазу, серед причин якого можуть бути генетично детерміновані зміни механізмів гемокоагуляції. Рецидиви сприсиняє також порушення рівноваги редокс-реакцій. Комплексне врахування досліджених клінічних і лабораторних показників може створити основу для напрацювання інформативної шкали стосовно прогнозування рецидивів виразкових кровотеч. Отримані дані засвідчують також необхідність корегування медикаментозних заходів, спрямованих на запобігання відновленню кровотечі. Висновки. 1. Рецидивні виразкові кровотечі частіше виникають у чоловіків, у хворих без виразкового анамнезу, у разі наявності класів II і I за Forrest та коморбідної патології II-III класів. 2. Лабораторними маркерами небезпеки рецидиву кровотечі $\epsilon$ високі показники вмісту первинних продуктів пероксидації ліпідів, рівня окиснення нейтральних білків, вмісту фібринази, низькі показники рівня окиснення основних білків та вмісту глутатіону відновленого і каталази, неферментаційної фібринолітичної активності плазми, а також протромбінового індексу. 3. Генетичним маркером небезпеки рецидиву кровотечі $є$ поліморфізм G43A гена PAI-1.

Ключові слова: гостра виразкова кровотеча, рецидив кровотечі, прогнозування.

Незважаючи на успіхи консервативного і ендоскопічного лікування виразкових кровотеч, частота розвитку їх рецидивів залишається на сталому рівні [1-4]. Серед причин цього є недостатня надійність відомих визнаних методів прогнозування рецидивних кровотеч. Найчастіше для цього використовують шкали Forrest [5], Glasgow Blatchford [6], Rockall [7]. Утім спільним їхнім недоліком є відсутність патогенетичного обгрунтування, неврахування частини важливих чинників, що спричиняють відновлення геморагії. Отож пошук шляхів вирішення означеної проблеми залишається актуальним.

Мета дослідження: напрацювання комплексного підходу до прогнозування рецидивів виразкових кровотеч для створення інформативної шкали.

Матеріал і методи. 203 хворих на виразкову хворобу, у 167 з яких виникла гостра виразкова кровотеча. Чоловіків 135 (66,5\%), жінок - 68 (33,3\%). Середній вік становив 56,6 17 років.
Усім хворим проведене обстеження $i$ консервативне лікування згідно з протоколами [8]. У 24 хворих виник рецидив кро-вотечі. У половини паиієнтів кровотеча зупинена ін 'єкиійним гемостазом, у решти - хірургічним втручанням.

Очінювали клінічні показники, клас кровотечі за Forrest, клас коморбідності [9]. У 59 хворих провели визначення активності процесів окиснення ліпідів, білків і антиоксидантних чинників, фібринолітичної, протеолітичної активності плазми венозної крові, коагулограми. У 43 хворих провели генотипування PAI-1 (SERPINE 1), який $\epsilon$ інгібітором тканинного активатора плазміногена й урокінази за мутаиією $\mathrm{G} 43 \mathrm{~A}$.

Перевірку закону розподілу вибірок на нормальність проводили за допомогою критерію Шапіро-Вілка, для перевірки гіпотези про рівність середніх використовували U-критерій Вілкоксона. Статистичну залежність між величинами перевіряли иляхом визначення критерію Фішера, $\chi^{2}$-критерію за Пірсоном, зокрема, відповідність 
ро-зподілу генотипів рівновазі Харді-Вайнберга. Критичний рівень значущьості за перевірки статистичних гіпотез у иьому дослідженні приймали рівним 0,05. Аналіз проводили з використанням таблиць Microsoft $\AA$ Office Excel (build 11.5612.5703).

Результати дослідження та їх обговорення. Здебільшого, рецидиви ( $\mathrm{n}=11 \quad(45,8 \%)$ виникали протягом 2-3 доби після надходження, частіше у чоловіків - 17 (70,8\%), переважно ( $\mathrm{n}=15(62,5 \%)$ у хворих, що не мали виразкового анамнезу, а також за наявності коморбідної патології II-III класів.

У 7 хворих з рецидивами протягом ендоскопічного обстеження за надходження діагностували клас IA за Forrest, у 4 - IB, у 3 - IIA, у 6 - IIB, у 4 - IIC. У половини пацієнтів кровотеча зупинена ін'єкційним гемостазом, у решти - хірургічним втручанням.

У хворих з рецидивами кровотеч виявили найвищі параметри критеріїв активності пероксидного окиснення ліпідів і нейтральних білків. Натомість рівень окиснення основних білків був найнижчим поряд 3 найменшими параметрами показників активності антиоксидантної системи.

У таких пацієнтів були найнижчі параметри показників протромбіного індексу, неферментаційної фібринолітичної активності плазми, різко переважав уміст фібринази.

Водночас у хворих 3 рецидивними кровотечами статистично істотно переважала кількість носіїв мутантного алелю A $(\mathrm{p}<0,05)$. Окрім того, носії мутантного алелю А (генотипи GA та AA) в 4,75 раза частіше $(\mathrm{p}<0,05)$ траплялися серед пацієнтів із кровотечею, ніж у таких без кровотечі.
Отже, проведене дослідження за свідчує, що передумовами виникнення рецидивних виразкових кровотеч $є$ дисбаланс у системі гемостазу, серед причин якого можуть бути генетично детерміновані зміни механізмів гемокоагуляції. Рецидивам сприяє також порушення рівноваги редоксреакцій.

Комплексне врахування досліджених клінічних і лабораторних показників може скласти основу для напрацювання інформативної шкали стосовно прогнозування рецидивів виразкових кровотеч. Отримані дані засвідчують також необхідність корегування медикаментозних заходів, спрямованих на запобігання відновленню кровотечі.

Висновки. 1. Рецидивні виразкові кровотечі частіше виникають у чоловіків, у хворих без виразкового анамнезу, у разі наявності класів II і I за Forrest та коморбідної патології II-III класів. 2. Лабораторними маркерами небезпеки рецидиву кровотечі $є$ високі показники вмісту первинних продуктів пероксидації ліпідів, рівня окиснення нейтральних білків, вмісту фібринази, низькі показники рівня окиснення основних білків та вмісту глутатіону відновленого і каталази, неферментаційної фібринолітичної активності плазми, а також протромбінового індексу. 3. Генетичним маркером небезпеки рецидиву кровотечі $є$ поліморфізм G43A гена PAI-1.

Перспективи подальших досліджень. Доцільним є включення досліджених показників у шкалу прогнозування рецидивних виразкових кровотеч і подальша оцінка її можливого клінічного значення.

\section{Список використаної літератури}

1. Матвійчук БО, Рачкевич СЛ, Тумак ІМ, Король ЯА, Патер ЯЗ, Кушнірук ОІ, та ін. Прогнозування рецидиву виразкових кровотеч після ендоскопічного гемостазу. Acta medica Leopoliensia. 2015; 21(3):53-8.

2. Гринчук ФВ. Аналіз чинників ризику рецидивних виразкових кровотеч. Збірник матеріалів міжнародної наук.-практ. конф. Актуальні питання медичної теорії та практики; 2016 груд. 9-10; Дніпро. Дніпро: "Salutem"; 2016, с. 66-9.

3. Cheng HC, Wu CT, Chen WY, Yang EH, Chen PJ, Sheu BS. Risk factors determining the need for secondlook endoscopy for peptic ulcer bleeding after endoscopic hemostasis and proton pump inhibitor infusion. Endosc Int Open. 2016; 4(3):E255-E262. Доступно на: https://www.ncbi.nlm.nih.gov/pmc/articles/PMC4798837/ doi: 10.1055/s-0041-111499

4. Park SJ, Park H, Lee YC, Choi CH, Jeon TJ, Park JC, et al. Effect of scheduled second-look endoscopy on peptic ulcer bleeding: a prospective randomized multicenter trial. Gastrointest Endosc. 2018;87(2):457-465. doi: 10.1016/j.gie.2017.07.024.

5. Forrest JA, Finlayson ND, Shearman DJ. Endoscopy in gastrointestinal bleeding. Lancet. 1974;2(7877):394-7. doi: 10.1016/s0140-6736(74)91770-x

6. Blatchford $O$, Murray WR, Blatchford M. A risk score to predict need for treatment for uppergastrointestinal haemorrhage. Lancet. 2000;356(9238):1318-21.

7. Rockall TA, Logan RF, Devlin HB, Northfield TC. Risk assessment after acute upper gastrointestinal 
haemorrhage. Gut. 1996;38(3):316-21.

8. Фомін ПД, Усенко ОЮ, редактори. Невідкладна хірургія органів черевної порожнини (стандарти організації та професійно орієнтовані алгоритми надання медичної допомоги). Київ: Бібліотека «Здоров'я України»; 2018.354 с.

9. Гринчук ФВ. Нова шкала для оиінювання коморбідності в невідкладній абдомінальній хірургії. Аrt of Medicine. 2018;4(8):55-7.

\section{References}

1. Matviichuk BO, Rachkevych SL, Tumak IM, Korol YaA, Pater YaZ, Kushniruk OI, et al. Prohnozuvannia retsydyvu vyrazkovykh krovotech pislia endoskopichnoho hemostazu [Prognostication of recurrence of ulcer bleeding after endoscopic hemostasis]. Acta medica Leopoliensia. 2015;21(3):53-8. (in Ukrainian).

2. Grynchuk FV. Analiz chynnykiv ryzyku retsydyvnykh vyrazkovykh krovotech [Tha analysis of risk factors for recurrent ulcer bleeding]. In: Aktualni pytannia medychnoi teorii ta praktyky Proceedings of the international scientific and practical conference; 2016 Dec 9-10; Dnipro. Dnipro: Salutem; 2016. p. 66-9. (in Ukrainian).

3. Cheng HC, Wu CT, Chen WY, Yang EH, Chen PJ, Sheu BS. Risk factors determining the need for secondlook endoscopy for peptic ulcer bleeding after endoscopic hemostasis and proton pump inhibitor infusion. Endosc Int Open. [Internet] 2016 Feb 8 [cited 2019 Feb 19]; 4(3):E255-E262. Available from: https://www.ncbi.nlm.nih.gov/pmc/articles/PMC4798837/ doi: 10.1055/s-0041-111499

4. Park SJ, Park H, Lee YC, Choi CH, Jeon TJ, Park JC, et al. Effect of scheduled second-look endoscopy on peptic ulcer bleeding: a prospective randomized multicenter trial. Gastrointest Endosc. 2018;87(2):457-465. doi: 10.1016/j.gie.2017.07.024.

5. Forrest JA, Finlayson ND, Shearman DJ. Endoscopy in gastrointestinal bleeding. Lancet. 1974;2(7877):394-7. doi: 10.1016/s0140-6736(74)91770-x

6. Blatchford $O$, Murray WR, Blatchford M. A risk score to predict need for treatment for uppergastrointestinal haemorrhage. Lancet. 2000;356(9238):1318-21.

7. Rockall TA, Logan RF, Devlin HB, Northfield TC. Risk assessment after acute upper gastrointestinal haemorrhage. Gut. 1996;38(3):316-21.

8. Fomin PD, Usenko OYu, editors. Nevidkladna khirurhiia orhaniv cherevnoi porozhnyny (standarty orhanizatsii ta profesiino oriientovani alhorytmy nadannia medychnoi dopomohy) [Emergency surgery of the abdominal cavity (organizational standards and professionally oriented algorithms for providing medical care)]. Kyiv: Biblioteka "Zdorov'ia Ukrainy”; 2018. 354 p. (in Ukrainian).

9. Grynchuk FV. Nova shkala dlia otsiniuvannia komorbidnosti v nevidkladnii abdominalnii khirurhii [New scale for assessing comorbidity in emergency abdominal surgery]. Art of Medicine. 2018;4(8):55-7. (in Ukrainian).

\section{КОМПЛЕКСНАЯ ОЦЕНКА МАРКЕРОВ РЕЦИДИВНЫХ ЯЗВЕННЫХ КРОВОТЕЧЕНИЙ}

Резюме. Частота развития рецидивов язвенных кровотечений остается на постоянном уровне. Шкалы Forrest, Glasgow Blatchford, Rockall недостаточно надежны. Цель работы. Наработка комплексного подхода к прогнозированию рецидивов язвенных кровотечений для создания информативной шкалы. Материал и методы. 203 больных язвенной болезнью, у 167 из которых возникло острое кровотечение. В 24 больных возник рецидив кровотечения. Оценивали клинические показатели, класс кровотечения по Forrest, класс коморбидности, активность процессов окисления липидов, белков и антиоксидантных факторов, фибринолитической, протеолитической активности плазмы венозной крови, коагулограмму. Провели генотипирование РАИ-1 (SERPINE 1). Установлено, что предпосылками возникновения рецидивов язвенных кровотечений является дисбаланс в системе гемостаза, среди причин которого могут быть генетически детерминированы изменения механизмов гемокоагуляции. Рецидивам способствует также нарушение равновесия окислительно-восстановительных реакций. Комплексный учет исследованных клинических и лабораторных показателей может создать основу для разработки информативной шкалы для прогнозирования рецидивов язвенных кровотечений. Полученные данные свидетельствуют также о необходимости корректировки медикаментозных мероприятий, направленных на предотвращение восстановлению кровотечения. Выводы. 1. Рецидивные язвенные кровотечения чаще возникают у мужчин, у больных без язвенного анамнеза, при наличии классов II и I по Forrest и коморбидной патологии II-III классов. 2. Лабораторными маркерами опасности рецидива кровотечения являются высокие показатели содержания первичных продуктов перекисного окисления липидов, уровня окисления нейтральных белков, содержания фибриназы, низкие показатели уровня окисления основных белков и содержания глутатиона восстановленного и каталазы, неферментативной фибринолитической активности плазмы, а также протромбинового индекса. 3. Генетическим маркером опасности 
рецидива кровотечения является полиморфизм G43A гена PAI-1.

Ключевые слова: острое язвенное кровотечение; рецидив кровотечения; прогнозирование.

\section{A COMPREHENSIVE EVALUATION OF RELAPSING PEPTIC ULCER BLEEDING MARKERS}

Abstract. The incidence of recurrent ulcerative bleeding is constant. The scales developed by Forrest, Glasgow Blatchford, Rockall are not reliable enough. The objective of the study: to develop a comprehensive approach to the prognosis of relapse of ulcer bleeding in order to create an informative scale. Material and methods: 203 patients with peptic ulcer disease including 167 patients with acute ulcer bleeding. 24 patients had a relapse of bleeding. The following clinical parameters were evaluated: bleeding class by Forrest, comorbidity class, activity of lipid oxidation processes, proteins and antioxidant factors, fibrinolytic, proteolytic activity of venous blood plasma, coagulogram. Genotyping PAI-1 (SERPINE 1) was made as well. Imbalance in the hemostasis system was found to be one of the preconditions of relapsing ulcerous bleedings among which causes can be genetically determined changes in mechanisms of hemocoagulation. Disturbance of the balance of redox reactions also contributes to recurrent bleeding. A comprehensive registration of the studied clinical and laboratory parameters can be the basis for developing an informative to predict recurrent ulcer bleedings. The obtained data also confirm the need for correction of medical measures aimed at preventing the restoration of bleeding. Conclusions 1. Recurrent ulcerative bleeding occurs more often in men, in patients without ulcer history, in the presence of Class II and I by Forrest and Comorbidity II-III classes. 2. High criteria of primary lipid peroxidation products, the level of neutral proteins oxidation, fibrinase, low levels of alkaline proteins oxidation, reduced glutathione, catalase, non-enzymatic fibrinolytic activity of plasma, prothrombin index are laboratory markers of the risk of bleeding relapse. 3. The polymorphism of the G43A gene of RAI-1 is a genetic marker for the risk of recurrent bleeding.

Keywords: acute ulcer bleeding, bleeding relapse, prognosis.

\section{Відомості про автора}

Дутка Іван Іванович - асистент кафедри догляду за хворими та вищої медсестринської освіти Вищого державного навчального закладу України «Буковинський державний медичний університет», м. Чернівці.

Information about authors:

Dutka Ivan I. - Assistant Professor, Department of care for patients and higher nursing education, Higher Educational Establishment of Ukraine "Bukovinian State Medical University", Chernivtsi City.

Надійшла 14.03.2019 p.

Рецензент - проф. Сидорчук Р.І. (Чернівці) 